\title{
Educational Interventions and Glycemic Control: Integrative Review
}

\author{
Capellari Claudia*, Pinheiro da Costa Bartira E, Larre Anne, Pasin Debora, Cardoso Angelica, Vasconcelos Luísa de and Figueiredo Ana E
}

Pontifical Catholic University of Rio Grande do Sul - PUCRS, Porto Alegre, RS, Brazil

\begin{abstract}
Glycemic control is an important factor for individuals with diabetes prevent complications such as vascular and kidney disease. Educational interventions carried out by the health team, have the potential to support the necessary change in lifestyle, adherence to treatment and a restrictive diet. The aim of this review was to investigate the educational interventions, related to glycemic control in patients with diabetes, published by health professionals in the past 10 years. The following databases were queried:

Nursing Database (BDENF); Literature in the Health Sciences in Latin America and the Caribbean (LILACS); Medical Literature Analysis and Retrieval System Online (MEDLINE); Scientific Electronic Library Online (SCIELO); Education Resources Information Center (ERIC); and, American Psychological Association (PsycINFO). The descriptors used for the search were "Diabetes" AND "self-care" AND "health education", and the period ranged from 2005 to 2015 . The initial search resulted in 856 articles, which have gone through both title and summary and, then, to complete reading. After this phase, 11 articles were selected for a comprehensive review. The most cited professional in the intervention with patients was the nurse, in 09 of the 11 studies. Interventions included meeting groups, individual appointments, telephone coaching, advice by e-mail or website with informational material. Health education was predominant in all of them, and the recurring themes covered: disease knowledge, diet, glucose selfmonitoring and physical exercise. Follow-up time was of 06-36 months. The glycated hemoglobin was reduced in 09 out of the 11 articles. In conclusion, we can say that multidisciplinary interventions of health education are powerful tools for the greatest benefit to the patient, providing necessary support for coping with the disease.
\end{abstract}

Keywords: Diabetes; Self-care; Education health; Patient education as topic

\section{Introduction}

Diabetes is a frequent clinical situation that affects about 382 million people worldwide, reaching 471 million in 2035 [1]. In Brazil, research indicates $6.2 \%$ of the population as having diabetes, which represents more than 9 million individuals [2]. Regarding age, the higher incidence is identified from 45 years old on, with prevalence ranging from $8.5 \%$ to $22.1 \%$ [3].

The recognition of Diabetes Mellitus (DM) as an epidemic and the management of hyperglycemia as a key for reducing damage and chronic complications anchors the development of research and therapies. Both the Diabetes Control and Complications Trial (DCCT) and the United Kingdom Prospective. Diabetes Study (UKPDS), which are among the major studies on the subject, concluded that glycemic levels are directly proportional to complications in DM patients $[4,5]$. Since then, maintaining acceptable levels of glucose has shown benefits related to complications, particularly to those concerning microvasculopathy and neuropathy $[4,6,7]$.

Diabetes causes significant damages such as micro and macrovascular changes, which may culminate with nephropathy, retinopathy, diabetic foot, changes in intestinal motility and atherosclerotic vascular disease [6,8]. Among the complications of diabetes, cardiovascular and kidney diseases are amid the most costly regarding human suffering and expenditures for health systems [9].

For a successful diabetes treatment, the patient requires adjustments that go beyond the use of medications. Changes in lifestyle, adherence to drug therapy and restrictive diet are some of the initiatives for the success of the treatment. Such patients need the support and coaching from the multidisciplinary health team professionals, who have the role of informing the user about their disease and assist in decision-making
[8]. Under this context, non-pharmacological treatment anchored in health education is fundamental. Among the purposes of this type of intervention, patient instrumentation concerning knowledge of their disease, complications inherent in the pathology and therapeutic management is paramount for greater autonomy and better quality of life [10].

Thus, health professionals have a major role, for they not only provide information, but must also act as motivators, facilitators, and promoters of individuals' awareness contributing to treatment adherence, development of self-care ability and lifestyle change $[11,12]$. Based on these considerations, the following research question was formulated: From an educational point of view, how do health professionals intervene in the glycemic control of patients with diabetes?

The present study aimed to investigate what are the educational interventions related to glycemic control in diabetic patients, with Diabetes type I or II, published by health professionals in the last 10 years.

\section{Method}

This is a integrative review whose production went through the following steps: guiding question establishment; inclusion and

${ }^{*}$ Corresponding author: Capellari Claudia, Pontifical Catholic University of Rio Grande do Sul - PUCRS, 1673. Av. Ipiranga, 6681 Partenon - Porto Alegre, Brazil Tel: +55 5181715941 ; E-mail: capellaric@gmail.com

Received May 02, 2016; Accepted June 09, 2016; Published June 15, 2016

Citation: Capellari C, Pinheiro da Costa BE, Anne L, Debora P, Angelica C, et al. (2016) Educational Interventions and Glycemic Control: Integrative Review. J Diabetes Metab 7: 675. doi:10.4172/2155-6156.1000675

Copyright: (c) 2016 Capellari C, et al. This is an open-access article distributed under the terms of the Creative Commons Attribution License, which permits unrestricted use, distribution, and reproduction in any medium, provided the original author and source are credited. 
exclusion criteria selection; databases and descriptors selection; selection according to the title; selection after abstract reading; selection after comprehensive reading; included studies assessment; results interpretation and review presentation.

The present study was developed based on scientific production indexed in the following electronic databases: Nursing Database (BDENF); Literature in the Health Sciences in Latin America and the Caribbean (LILACS); Medical Literature Analysis and Retrieval System Online (MEDLINE); Scientific Electronic Library Online (SCIELO); Education Resources Information Center (ERIC); and, American Psychological Association (PsycINFO). The keywords used for the search were "Diabetes" AND "self-care" AND "health education", according to the Health Sciences Descriptors (DECS) and the Medical Subject Headings (MeSH). As for the MEDLINE database, we selected "clinical trial" and "randomized controlled trial" as filters due to a large number of pointed results.

The searches were conducted during the month of October, 2015. The time frame covered the period of 2005-2015.

As exclusion criteria were considered: studies involving children and adolescents; papers written in languages rather than Portuguese, English or Spanish; articles of literature review; articles regarding education for formal instruction in health; validation studies of instruments/ scales; articles which assessed only the knowledge of individuals about the disease; editorials; opinions of authorities; reports of committees or specializations; and, studies whose follow-ups were carried out in a period of less than 6 months (or those without follow-ups).

Firstly, a search among the cited repositories was provided, during which the studies were listed from their titles. Studies were included that presented educational interventions for patients with diabetes mellitus type I, II or both types, with at least 6 months of intervention. After the first scanning, those articles underwent a new selection, based on abstracts reading. The following step consisted in a complete reading of the papers, leaving 11 articles to be analyzed. Detailing of the work phases can be seen in Flow Chart 1.

\section{Results and Discussions}

The repository with the highest number of articles found was MEDLINE (358), followed by LILACS (204), SCIELO (112) BDENF (85), ERIC (73) and PsycINFO (24). MEDLINE also showed the largest number of articles included in this study (7).

The prevalent language was English, found in 10 of the 11 papers
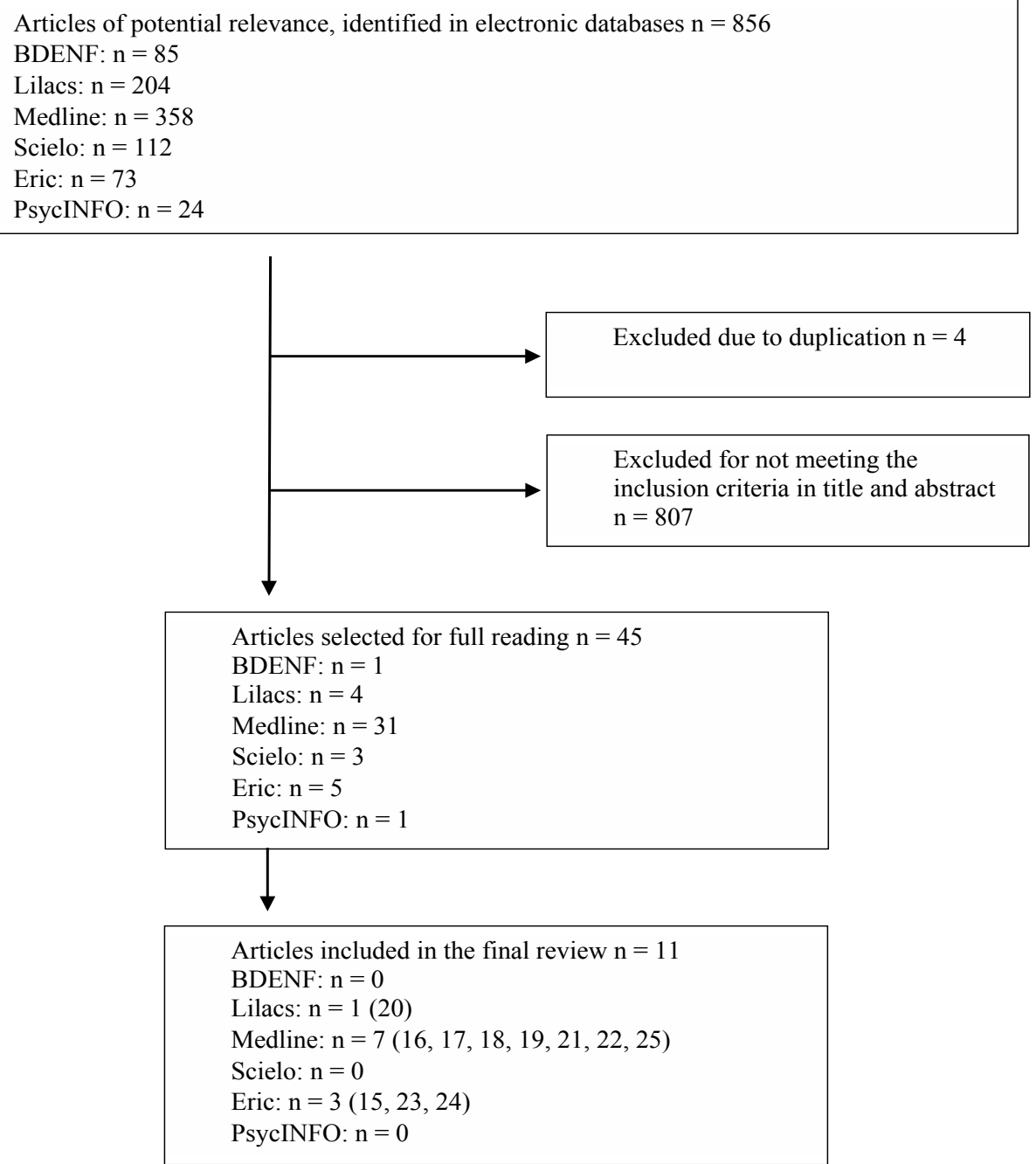

Flow Chart 1: Distribution of articles found and selected according to database. Porto Alegre, RS, 2015. 
selected for the final review. Only one Brazilian article of interest was identified, reflecting the paucity of the work done in the country as pointed out in the review by Borba and collaborators [13], detecting the need for studies with follow-ups of longer periods and dissemination in international journals.

During the comprehensive reading, articles that did not include the criterion of educational practice for the control and treatment of diabetes were excluded, as well as observational studies and those with follow-up time of less than 6 months. Regarding journals, 2 papers were published in Health Education Research, 2 articles in BMC Public Health and 1 article in each of the following titles: Internal Medicine Journal, Patient Education and Counseling, The Journal of Rural Health, Diabetes Research and Clinical Practice, Diabetic Medicine, Medical Informatics and Journal of Public Health (USP/ Brazil).

As to the participants of the selected studies, one study only included patients with DM type I [14-16] and another study included both patients with DM type I and type II [13]. The remaining studies included only patients with DM type II. The mean age of participants ranged between $45.1+16$ and 66.7 years +9 . Other characteristics can be seen in Table 1.

In relation to the professionals involved in the interventions portrayed in this study, the nurse was identified in 9 out of the 11 papers. Education in Health is part of the nursing practice environment, becoming an instrument to establish a reflexive-dialogical nursepatient relationship, in which the patient must be aware of his/her health-disease situation in order to have autonomy for transforming his/her own life [14].

As for design, we identified 5 randomized controlled trials [15-22], 1 cohort study [23], 1 before-after research study [24], and 1 quasiexperimental study with a control group [25]. All studies used disease knowledge strategies, which is reflected in the completion of some works as of patient empowerment, self-care ability and self-monitoring of blood glucose, improved foot care and bettered quality of life, as it can be seen in Table 1 .

Each of the studies was carried out in different countries. Although

\begin{tabular}{|c|c|c|c|c|}
\hline $\begin{array}{l}\text { Author/year/design/ } \\
\text { country }\end{array}$ & $\begin{array}{l}\text { Main characteristics of } \\
\text { participants }\end{array}$ & $\begin{array}{l}\text { Characterization of educational } \\
\text { interventions in health }\end{array}$ & Topics Addressed & Main Results \\
\hline $\begin{array}{l}\text { Merakou et al. [15] } \\
\text { Clinical Trial } \\
\text { Greece }\end{array}$ & $\begin{array}{c}\text { DM type II. } \\
\text { Mean age (years): } 63,8 \text { (control } \\
\text { group - CG); } 67,2 \text { (intervention } \\
\text { group - IG). } \\
\text { Gender: } 58,2 \% \text { male (CG); } \\
53,6 \% \text { male (IG). } \\
\text { Education (years): } 6 \text { to } 9 .\end{array}$ & $\begin{array}{l}\text { Individual coaching in medical } \\
\text { appointments and home visits. } \\
\text { Conversation Maps. }\end{array}$ & $\begin{array}{c}\text { General knowledge of } \\
\text { diabetes; living with diabetes; } \\
\text { diet and practice of physical } \\
\text { activity. }\end{array}$ & $\begin{array}{l}\text { HbA1c reduction in CG ( } 8,2 \% \text { to } \\
7,7 \% \text { ) and IG (from } 6,9 \% \text { to } 6,3 \%) \text {. } \\
\text { There was no significant difference } \\
\text { in BMI and lipid profile. Better } \\
\text { control observed in those with } \\
\text { educational support. }\end{array}$ \\
\hline $\begin{array}{l}\text { Hermanns et al. [16] } \\
\text { Clinical Trial } \\
\text { Germany }\end{array}$ & $\begin{array}{c}\text { DM type I. } \\
\text { Mean age (years): } 45,1(\mathrm{CG}) \\
45,9(\mathrm{IG}) \\
\text { Gender: } 49,4 \% \text { female (CG); } \\
38,3 \% \text { female (IG). } \\
\text { Education (years): mean } 11,2 .\end{array}$ & $\begin{array}{l}\text { Individual appointments, } 12 \text { sessions. } \\
\text { PRISMA method (Program for diabetes } \\
\text { education and treatment for a self- } \\
\text { determined living with type } 1 \text { diabetes). } \\
\text { Empowerment and self-care approach. }\end{array}$ & $\begin{array}{c}\text { General knowledge of } \\
\text { diabetes; coexistence and } \\
\text { emotional problems involved } \\
\text { in the disease, complications; } \\
\text { self-monitoring of glucose, } \\
\text { motivation; knowledge and } \\
\text { skills for food preparation; } \\
\text { physical exercise; quality of } \\
\text { life; social support. }\end{array}$ & $\begin{array}{l}\mathrm{HbA} 1 \mathrm{c} \text { reduction in IG }(8,3 \% \text { to } \\
7,9 \%) \text {; improvement in the control } \\
\text { of blood glucose fluctuations and } \\
\text { enhanced knowledge on diabetes } \\
\text { in the IG. }\end{array}$ \\
\hline $\begin{array}{l}\text { Adachi et al.[17] } \\
\text { Clinical Trial } \\
\text { Japan }\end{array}$ & $\begin{array}{c}\text { DM type II. } \\
\text { Mean age (years): } 62,3 \text { (CG); } \\
60,4(\mathrm{GI}) \\
\text { Gender: } 58 \% \text { female (CG); } \\
55 \% \text { female (IG). } \\
\text { Education (years): uninformed. }\end{array}$ & $\begin{array}{l}4 \text { individual appointments with a } \\
\text { nutritionist. SILE method. }\end{array}$ & $\begin{array}{l}\text { Glycemic control; daily } \\
\text { activities for glucose control; } \\
\text { stress management. }\end{array}$ & $\begin{array}{c}\mathrm{HbA} 1 \mathrm{c} \text { reduction in IG }(7,6 \% \text { to } \\
6,7 \%) \text { and in the control group } \\
(7,3 \% \text { to } 7 \%) \text {. The IG also showed } \\
\text { BMI reduction and increase in } \\
\text { vegetable intake. }\end{array}$ \\
\hline $\begin{array}{l}\text { Rygg et al. [18] } \\
\text { Clinical Trial } \\
\text { Norway }\end{array}$ & $\begin{array}{c}\text { DM type II. } \\
\text { Mean age (years): } 66 . \\
\text { Gender: } 55 \% \text { male. } \\
\text { Education (years): } 27 \% \\
\text { graduates. }\end{array}$ & $\begin{array}{l}\text { Group meetings of } 8 \text { to } 10 \text { patients. } 3 \\
\text { gatherings. Interactive reading, skills } \\
\text { training (exercise, capillary glucose } \\
\text { measurement and problem solving), } \\
\text { group discussion. }\end{array}$ & $\begin{array}{l}\text { General knowledge of } \\
\text { diabetes; physical exercise; } \\
\text { diet; glycemic control. }\end{array}$ & $\begin{array}{l}\text { Slight increase in mean } \mathrm{HbA} 1 \mathrm{c} \\
\text { during } 12 \text { months of intervention } \\
\text { in both groups ( } 7,1 \% \text { to } 7,2 \% \\
\text { in IG and } 6,9 \% \text { to } 7,2 \% \text { in } \mathrm{CG}) \text {. } \\
\text { However, an analysis was made } \\
\text { only of patients with HbA1c } \\
\text { above } 7,7 \% \text { at the start of the } \\
\text { study, which showed a significant } \\
\text { reduction in the intervention group } \\
\text { ( } 9 \% \text { to } 8,2 \% \text { ) compared with } \\
\text { the CG (remained } 8,8 \% \text { ). Also } \\
\text { diabetes and self-care knowledge } \\
\text { improvement. }\end{array}$ \\
\hline $\begin{array}{l}\text { Salinero-Fort et al. [19] } \\
\text { Clinical Trial } \\
\text { Spain }\end{array}$ & $\begin{array}{l}\text { DM type II. } \\
\text { Mean age (years): } 66,7 \text {. } \\
\text { Gender: } 51,6 \% \text { female. } \\
\text { Education (years): uninformed. }\end{array}$ & $\begin{array}{l}\text { Individual coaching during home } \\
\text { visits. PRECEDE Educational model } \\
\text { (Predisposing, Reinforcing, Enabling, } \\
\text { Causes in Educational Diagnosis, and } \\
\text { Evaluation). }\end{array}$ & $\begin{array}{l}\text { Self-monitoring of glucose; } \\
\text { physical exercise; diet; } \\
\text { adherence to drug treatment; } \\
\text { smoking cessation. }\end{array}$ & $\begin{array}{c}\text { Slight reduction in the mean } \\
\mathrm{HbA} 1 \mathrm{c} \text { in IG }(7,05 \% \text { to } 7,02 \%) \text { and } \\
\text { increased in CG }(7,36 \% \text { to } 7,38 \\
\%) \text {. Also blood pressure reduction } \\
\text { in IG. }\end{array}$ \\
\hline
\end{tabular}




\begin{tabular}{|c|c|c|c|c|}
\hline $\begin{array}{c}\text { Torres et al. [20] } \\
\text { Clinical Trial } \\
\text { Brazil }\end{array}$ & $\begin{array}{l}\text { DM type II. } \\
\text { Mean age (years): } 60,6 \text {. } \\
\text { Gender: } 75 \% \text { female. } \\
\text { Education (years): } 78,8 \% \\
\text { primary school or less. }\end{array}$ & $\begin{array}{l}\text { Group meetings of } 13 \text { patients; } 5 \\
\text { educational modules with professional } \\
\text { participation of a multidisciplinary } \\
\text { team led by a nurse. Comparison with } \\
\text { individual assistance twice a month, } \\
\text { one with nutritionist and another with an } \\
\text { occupational therapist. }\end{array}$ & $\begin{array}{l}\text { General knowledge } \\
\text { of diabetes; disease } \\
\text { complications; diet; practice of } \\
\text { physical exercise; foot care. }\end{array}$ & $\begin{array}{l}\text { The interventions showed } \\
\text { positive results. There was not } \\
\text { a statistically significant HbA1c } \\
\text { reduction between the two groups } \\
\text { (individual intervention (from } 9,3 \% \\
\text { to } 7,8 \% \text { ) and group intervention } \\
\text { (from } 9,3 \% \text { to } 7,6 \% \text { )). There was } \\
\text { not improvement in the other } \\
\text { variables. The both interventions } \\
\text { showed knowledge of diabetes } \\
\text { improvement. }\end{array}$ \\
\hline $\begin{array}{l}\text { Varney et al. [21] } \\
\text { Clinical Trial } \\
\text { Australia }\end{array}$ & $\begin{array}{c}\text { DM type II. } \\
\text { Mean age (years): } 64 \text { (CG); } \\
59 \text { (IG). } \\
\text { Gender: } 64 \% \text { male (CG); } 72 \% \\
\text { male (IG). } \\
\text { Education (years): uninformed. }\end{array}$ & $\begin{array}{l}\text { Telephone coaching for six months } \\
\text { with monthly sessions from } 20 \text { to } 45 \\
\text { minutes. Participants received } 6 \text { calls } \\
\text { during } 6 \text { months. }\end{array}$ & $\begin{array}{l}\text { Diet (orientations focused on } \\
\text { the reduction of saturated } \\
\text { fat, increase fiber intake } \\
\text { and carbohydrate control); } \\
\text { treatment adherence and } \\
\text { self-care; foot care; lifestyle; } \\
\text { medication; and physical } \\
\text { exercise. }\end{array}$ & $\begin{array}{l}\text { IG: significantly higher reduction in } \\
\text { the HbA1c (de } 8,2 \% \text { para } 7,7 \%) \text {. } \\
\text { However, } 12 \text { months after the end } \\
\text { of the intervention, HbA1c had } \\
\text { returned to baseline levels. }\end{array}$ \\
\hline $\begin{array}{l}\text { Deakin et al. [22] } \\
\text { Clinical Trial } \\
\text { United Kingdom }\end{array}$ & $\begin{array}{c}\text { DM type II. } \\
\text { Mean age (years): } 61,8(\mathrm{CG}) \\
61,3(\mathrm{IG}) \\
\text { Gender: } 52 \% \text { male. } \\
\text { Education (years): 16,2 (CG); } \\
15,3(\mathrm{IG}) .\end{array}$ & $\begin{array}{c}\text { Group meetings of } 16 \text { participants } \\
\text { and } 4 \text { to } 8 \text { caregivers at each meeting } \\
\text { (average); } 6 \text { sessions once a week, } \\
\text { two hours each. X-PERT method, } \\
\text { based on empowerment and learning } \\
\text { breakthrough. }\end{array}$ & $\begin{array}{l}\text { Breakthrough as a way of } \\
\text { learning; skills and confidence } \\
\text { for the increasing of self- } \\
\text { management in diabetes. }\end{array}$ & $\begin{array}{c}\text { In IG there was a } \mathrm{HbA} 1 \mathrm{c} \text { reduction } \\
\text { from } 7,7 \% \text { to } 7,1 \% \text { in } 14 \text { months, } \\
\text { being } 0.3 \% \text { after four months, } \\
\text { showing long-term effect. In CG } \\
\text { there was } \mathrm{HbA} 1 \mathrm{c} \text { increase from } \\
7,7 \% \text { to } 7,8 \% \text {. }\end{array}$ \\
\hline $\begin{array}{l}\text { Dettori et al. [23] } \\
\text { Cohort Study } \\
\text { USA }\end{array}$ & $\begin{array}{c}\text { DM type I or II. } \\
\text { Mean age (years): } 65 . \\
\text { Gender: } 57 \% \text { female. } \\
\text { Education (years): uninformed. }\end{array}$ & $\begin{array}{c}\text { Group meetings with patients and } \\
\text { health staff. E-mails with educational } \\
\text { materials and survey on satisfaction } \\
\text { and management difficulty. Phone calls. } \\
\text { Motivational techniques. Provision of } \\
\text { free access to local library, a journal } \\
\text { with patients' news, dissemination } \\
\text { of information in local and electronic } \\
\text { media. }\end{array}$ & $\begin{array}{l}\text { Glycated hemoglobin, blood } \\
\text { pressure, lipid profile, foot } \\
\text { care. }\end{array}$ & $\begin{array}{c}\mathrm{HbA} 1 \mathrm{c} \text { reduction from } 7,2 \% \text { to } \\
6,8 \% \text {. Improvement in foot care } \\
\text { and satisfaction regarding diabetes } \\
\text { care. }\end{array}$ \\
\hline $\begin{array}{c}\text { Molsted et al. [24] } \\
\text { Before-after Research } \\
\text { Study } \\
\text { Denmark }\end{array}$ & $\begin{array}{c}\text { DM type II. } \\
\text { Mean age (years): } 61 \\
\text { Gender: } 53 \% \text { female. } \\
\text { Education (years): } 55 \% 8 \text { years } \\
\text { and more. }\end{array}$ & $\begin{array}{l}\text { Group meetings of } 12 \text { patients; three } \\
\text { educational modules. Empowerment } \\
\text { philosophy. Practical skills training in } \\
\text { order to prepare healthy food and visits } \\
\text { to supermarket with nutritional tables } \\
\text { analysis. }\end{array}$ & $\begin{array}{l}\text { Empowerment strategies; } \\
\text { self-care ability; living with } \\
\text { diabetes; self-monitoring } \\
\text { of glucose; drug treatment; } \\
\text { prevent complications; } \\
\text { practice of physical exercise. } \\
\text { Motivation. }\end{array}$ & $\begin{array}{l}\mathrm{HbA} 1 \mathrm{c} \text { reduction from } 7,34 \% \text { to } \\
6,88 \% \text { and BMI reduction, lipid } \\
\text { profile improvement. Quality of } \\
\text { life QOL: overall health aspects } \\
\text { improvement. }\end{array}$ \\
\hline $\begin{array}{l}\text { Lee et al. [25] } \\
\text { Quasi-experimental Study } \\
\text { Taiwan }\end{array}$ & $\begin{array}{c}\text { DM type II. } \\
\text { Mean age (years): } 65,97 \text { (CG); } \\
61,15 \text { (IG). } \\
\text { Gender: } 54 \% \text { female (CG); } \\
43 \% \text { female (IG). } \\
\text { Education (years): most with } \\
\text { high school or more. }\end{array}$ & $\begin{array}{l}\text { Intervention and control groups were } \\
\text { treated in accordance with educational } \\
\text { guidelines in diabetes group. In the } \\
\text { intervention group, educational action } \\
\text { was proposed via Internet, through the } \\
\text { POEM system }\end{array}$ & $\begin{array}{c}\text { General knowledge of } \\
\text { diabetes; foot care; self- } \\
\text { monitoring of glucose; } \\
\text { management of hypoglycemia; } \\
\text { insulin injection; diet; } \\
\text { physical exercise; drugs for } \\
\text { the treatment of diabetes; } \\
\text { diabetes complications and } \\
\text { generalities. }\end{array}$ & $\begin{array}{l}\text { IG had significantly higher } \\
\text { reduction in the HbA1c }(8,56 \% \\
\text { to } 7,19 \%) \text { in the CG }(8,9 \% \text { to } \\
7,77 \%) \text {. The IG also had better } \\
\text { control of their fasting glucose and } \\
\text { total cholesterol than those in the } \\
\text { control group. }\end{array}$ \\
\hline
\end{tabular}

Table 1: Characterization of the papers.

there is great diversity among the populations studied in the articles, the benefits of educational interventions are very similar, which may suggest the relevance of such interventions in glycemic control, diabetes management and even the quality of life of the diabetic population in general, independently of cultural characteristics.

Considering the study area, only one survey was conducted in the countryside [23]. The follow-up time of each study was varied: 36 months (23); 24 months (19); 14 months (22); 12 months (18,21,24); 9 months (25) and 6 months (15-17,20).

All studies were performed with diabetic patients over 18 years old and reflect initiatives taken by health teams around the world. It can be inferred that professionals believe that knowledge on self-monitoring of the disease is an important tool for a better clinical outcome. Patient education is a crucial tool for better diabetes control, to prevent complications and reduce costs [26].

Regarding the type of intervention, 5 studies used group meetings
[15,16,18,22,24]. The study of Dettori et al. [23], which was performed in a rural area, consisted in many ways of intervention, including phone calls, e-mails, newsletters, education group workshops and provision of material on diabetes at a local library, while Varney et al. [21] made use of phone calls only. Adachi et al. [17] relied on individual instructions face-to-face or by phone to perform their interventions. As for the study provided by Salinero-Fort et al. [19], the interventions were also individual; however, accomplished through home visits. Lee et al. [25] based their work on information technology, providing instructions, books and video lessons through a website. Torres et al. [20] made a comparison between the individual and group interventions. All studies reported in the present article provided some sort of benefit to patients.

Among the topics covered in health education interventions, we highlight the focus on general knowledge about diabetes, risk factors, self-monitoring of blood glucose, prevention of complications, diet, and physical activities. Some studies used empowerment techniques 
$[16,22,24,26]$ and showed a significant glycated hemoglobin (HbA1c) reduction. The intervention carried out by Merakou et al. [15] privileged discussion, questions, answers, and scenario analysis (rather than simply provide information) and obtained excellent results.

The HbA1c, evidenced from the UKPDS study (5) and DCCT (4) as an important parameter, presented reduction in 9 out of the 11 studies analyzed. Both studies in which there was no HbAlc reduction in the intervention group, the increase of this variable in the control group is highlighted $[16,18]$. Although not always significant, HbAlc reduction represents the impact of the educational intervention over the biochemical parameter.

Variables related to the lipid profile showed improvement in only one study [24]. The reduction of body mass index (BMI) was achieved in 2 out of the 7 studies that evaluated this variable [17,24]. Albeit a reduction of this index in the short term is achievable, there is no guarantee that this result will be maintained in the long term. In addition, small weight reductions do not impact directly on the improvement of cardiovascular events such as stroke and acute myocardial, as pointed out by the Look Ahead study [27].

In Brazil, health education publications focusing on diabetes using the philosophy of empowerment were not found. According to Molsted et al. [24], empowerment enables the acquisition of individual emancipation and the necessary awareness for overcoming external aid dependency, aiming to stimulate the autonomy of the patient.

Regarding the study performed in the rural area [23], with a followup of 36 months, there was a considerable reduction in HbAlc. However, due to high costs, it is not always possible to carry out an intervention for such an extensive period. Thereupon, the use of empowerment techniques may contribute to the patient in order to maintain their goals, even without the external motivation of an educative program.

Hermans et al. [16] compared two in-group interventions of the same duration. The group that underwent empowerment interventions and self-care approaches (PRIMAS METHOD) showed good results in reducing $\mathrm{HbAlc}$. The main differential of this program is the autonomy stimulation, through spreadsheets with individual goals and targets, as well as in the study of Adachi et al. [17]. However, the later used a single intervention. Probably setting short-term goals is important for staff motivation, which may have contributed to the optimal results obtained in both studies.

Rygg et al. [18], as mentioned before, found no significant alteration in HbAlc twelve months after the end of the intervention, but there was an increase in $\mathrm{HbAlc}$ in the control group. After a short period of intervention, it is difficult to obtain results that are perpetuated. Despite that, in an isolated analysis of a group with baseline HbA1c higher than 7.7\%, there was a significant reduction in HbAlc in 12 months, which indicates the low efficiency of this type of treatment in patients with intermediate level of $\mathrm{HbAlc}$, as suggested by the American Diabetes Association [28].

Compared to long-term follow-up studies, as the one of Molested et al. [24] the study of Salinero Fort et al. [19] had less significant results. We emphasize two points that may be related to the difference in results. First, the study of Salinero-Fort et al. [19] used home visits, while that of Molested et al. [24] used group interventions. In addition to lower cost, group interventions appear to be more effective than individual, as suggested by the results also found in Torres et al. [20]. Besides that, Molsted et al. [24] availed themselves of empowerment techniques during education practice.
Torres et al. [20] compared in-group and individual interventions. The intervention in a group achieved better results, both in terms of $\mathrm{HbAlc}$ reduction and diabetes knowledge. The higher number of professionals involved, contact time of a longer period and more sessions may have contributed to this result, as the article itself acknowledges. Yet, greater interactivity and the appreciation of the participants' experiences may have exerted greater incentive than individual action, contributing to this result.

The work accomplished by Varney et al. [21] shows the importance of continuous monitoring. After telephone interventions, the $\mathrm{HbAlc}$ of the patients had significant reduction. However, 12 months after the end of the intervention, HbAlc returns to baseline levels. This may indicate that interventions should be continuous so that the good results do not recede over time. We can compare the studies by Varney et al. [21] and by Deakin et al. [22]. While the first is performed in a single intervention and the second in a group intervention, both had 6 sessions and long-term monitoring after the end of the interventions. While the study by Varney et al. [21] HbAlc receded to baseline levels after 12 months, the one by Deakin et al. [22] shows that HbAlc continued to reduce up to 14 months after the intervention. The main difference is in the empowerment techniques applied by Deakin et al. [22]. Probably the empowerment enables a higher self-control in the patient, which is not dependent on the health team interventions in a long-term, and develop greater autonomy for managing their health. Furthermore, as previously discussed, the study by Deakin et al. [22] may have obtained better results for being an in-group intervention.

The paper by Lee et al. [25] brings a complementary intervention concurrent with group education, which is rather efficient. The use of a website with guidelines on diabetes had good results in reducing $\mathrm{HbAlc}$ if compared to the control group. The article shows that the addition of an electronic mean for monitoring the conventional educational treatment can improve intervention results.

If, on the one hand, some clinical variables have not presented the desired range especially when it comes to blood glycemic control the gold standard ( $\mathrm{HbAlc}$ ), on the other hand, variables of treatment adhesion, quality of life, knowledge, foot care, diet and disease selfmonitoring appear as positive points of the performed interventions. Such variables may have a direct impact in the quality of daily life, in the living with the disease and in preventing complications, such as diabetic foot and diabetic neuropathy.

Considering the current situation of the global outbreak of diabetes, this disease concentrates the highest costs in the health area among the chronic diseases [29]. That being said, the cost-effective implementation of educational programs for self-care in primary health care would be advantageous, once investments for the implementation of these basic programs are minimal, and, in the long run, financial expenditures related to the treatment of the disease and its complications would be reduced in relevant manner.

Lastly, it is worth noticing that multidisciplinary interventions are powerful tools for the greater benefit of the patient. Group and individual work, which are supposed to respect patient's knowledge, are initiatives aiming to overcome the fragmentation of care, providing the patient with autonomy and power of decision about his life. According to Borba [13], these practices are focused on the process of paradigms shift regarding the traditional education system, which is a reflection of the sanitarian care model, approaching it to the problematizing and dialogical education in order to promote health. 
Citation: Capellari C, Pinheiro da Costa BE, Anne L, Debora P, Angelica C, et al. (2016) Educational Interventions and Glycemic Control: Integrative Review. J Diabetes Metab 7: 675. doi:10.4172/2155-6156.1000675

\section{Final Considerations}

Health education practices for the control and treatment of diabetes performed around the world show the engagement of health professionals in providing patients with autonomy and expansion of self-care, aiming at improved clinical outcomes and quality of life. The involvement of a nursing expert is seen in most studies, showing that health education is an intrinsic feature of such professional.

Limitations of the study are situated, especially, in the follow-up. Therefore, it is suggested that researches should be developed with longer follow-ups, including clinical variables and $\mathrm{HbAlc}$ which allow a systematic and subsequent comparison of results obtained with such interventions. It is also suggested researches as with the engagement of a multidisciplinary health team.

\section{References}

1. Guariguata L, Whiting $D$, Hambleton I, Beagley J, Linnenkamp U, et al. (2014) Global estimates of diabetes prevalence for 2013 and projections for 2035 . Diabetes Research and Clinical Practice 2: 137-149.

2. Iser BPM, Stopa SR, Chueiri PS, Szwarcwald CL, Malta DC, et al. (2015) Selfreported diabetes prevalence in Brazil: results from National Health Survey 2013. Epidemiologia e Serviagos de Saade 24: 305-314.

3. VIGITEL (2013) Surveillance of risk factors and protection for diseases cr'nicaspor inquest telef'nico. Brasilia (DF): Ministry of Health 62: 12-35.

4. DCCT (1993) The effect of intensive treatment of diabetes on the development and progression of long-term complications in insulin-dependent diabetes mellitus. The Diabetes Control and Complications Trial Research Group. N Engl J Med 329: 977-986

5. No authors listed (1998) Intensive blood-glucose control with sulphonylureas or insulin compared with conventional treatment and risk of complications in patients with type 2 diabetes (UKPDS 33). UK Prospective Diabetes Study (UKPDS) Group. Lancet 352: 837-853.

6. Bem AF, Kunde J (2006) A importancence of determining haemoglobin and glucose levels in type 2 Diabetes patients. J Bras Patol Med Lab 42.

7. Nathan DM, Buse JB, Davidson MB, Ferrannini E, Holman RR, et al. (2009) Medical management of hyperglycemia in type 2 diabetes: a consensus algorithm for the initiation and adjustment of therapy: a consensus statement of the American Diabetes Association and the European Association for the Study of Diabetes. Diabetes Care 32: 193-203.

8. Oliveira KCSD, Zanetti ML (2011) Knowledge and usuajrios attitude with diabetes mellitus in an up Service of the bajsica a health. Journal of Nursing School USP 45:862-868.

9. Mengue SS, Tavares NU, Costa KS, Malta DC, Silva Júnior JB (2015) Sources for obtaining drugs for hypertension in Brazil: results from the National Health Survey, 2013. Rev Bras Epidemiol 18 Suppl 2: 192-203.

10. National parameters in democratic (1998) Evolution the diabetes prevalance and this associated. Epidemological Service 21: 7-19.

11. SBD (2015) Guidelines of the Brazilian Society of Diabetes Saeo Paulo : AC Pharmaceutical 8: 25-48.

12. Assunaoaeo TS, Ursine PGS (2008) Study factors associated with ADESA $£$ Oao treatment $n A £$ farmacol $\tilde{A}^{3}$ gico in the patients with diabetes mellitus assisted by the Healthcare Família Program, Ventosa, Belo Horizonte. cyano Healthcare Collective13: 2189-2197.

13. Davies MJ, Heller S, Skinner TC, Campbell MJ, Carey ME, et al. (2008) Effectiveness of the diabetes education and self management for ongoing and newly diagnosed (DESMOND) programme for people with newly diagnosed type 2 diabetes: cluster randomised controlled trial. BMJ 336: 491-495.

14. Borba AK, Marques AP, Leal MC, Ramos RS (2012) Educational practices for diabetes mellitus: integrative literature review. Rev Gaucha Enferm 33: 169-176.
15. Sousa LBD, Torres CA, Pinheiro PNDC, Pinheiro AKB (2010) Practises of Education in the Healthcare in Brazil: autoimmune the nursing. Rev Nurse UERJ 18: 55-60

16. Merakou K, Knithaki A, Karageorgos G, Theodoridis D, Barbouni A (2015) Group patient education: effectiveness of a brief intervention in people with type 2 diabetes mellitus in primary health care in Greece: a clinically controlled trial. Health Educ Res 30: 223-232.

17. Hermanns N, Kulzer B, Ehrmann D, Bergis-Jurgan N, Haak T (2013) The effect of a diabetes education programme (PRIMAS) for people with type 1 diabetes: results of a randomized trial. Diabetes Res Clin Pract 102: 149-157.

18. Adachi M, Yamaoka K, Watanabe M, Nishikawa M, Kobayashi I, et al. (2013) Effects of lifestyle education program for type 2 diabetes patients in clinics: a cluster randomized controlled trial. BMC Public Health 13: 467-470.

19. Rygg Lo, Rise MB, Gronning K, Steinsbekk A (2012) Efficacy of ongoing group based diabetes self-management education for patients with type 2 diabetes mellitus. A randomised controlled trial. Patient Educ Couns 86: 98-105.

20. Salinero-Fort MA, Carrillo-de Santa Pau E, Arrieta-Blanco FJ, AbanadesHerranz JC, MartÃn-Madrazo C, (2011) Effectiveness of PRECEDE model for health education on changes and level of control of $\mathrm{HbA1c}$, blood pressure, lipids, and body mass index in patients with type 2 diabetes mellitus. BMC Public Health. 11: 267.

21. Torres HDC, Franco LJ, Stradioto MA, Hortale VA, Schall VT (2009) Evaluation of group and individual strategies in a diabetes education program. Revista de Saode Publica 43: 291-298.

22. Varney J, Weiland T, Inder W, Jelinek G (2014) Effect of hospital-based telephone coaching on glycaemic control and adherence to management guidelines in type 2 diabetes, a randomised controlled trial. Internal medicine journal. 44: 890-897.

23. Deakin T, Cade J, Williams R, Greenwood D (2006) Structured patient education: the diabetes X-PERT Programme makes a difference. Diabetic medicine: a journal of the British Diabetic Association 23: 944.

24. Dettori N, Flook BN, Pessl E, Quesenberry K, Loh J, et al. (2005) Improvements in care and reduced self-management barriers among rural patients with diabetes. J Rural Health 21: 172-177.

25. Molsted S, Tribler J, Poulsen PB, Snorgaard O (2012) The effects and costs of a group-based education programme for self-management of patients with Type 2 diabetes. A community-based study. Health Educ Res 27: 804-813.

26. Lee TI, Yeh YT, Liu CT, Chen PL (2007) Development and evaluation of a patient-oriented education system for diabetes management. International journal of medical informatics 76: 655-663.

27. Rickheim PL, Weaver TW, Flader JL, Kendall DM (2002) Assessment of group versus individual diabetes education: a randomized study. Diabetes Care 25: 269-274.

28. Look AHEAD Research Group, Wing RR, Bolin P, Brancati FL, Bray GA, et al. (2013) Cardiovascular effects of intensive lifestyle intervention in type 2 diabetes. N Engl J Med 369: 145-154.

29. Association AD (2010) Diagnosis and classification of diabetes mellitus Diabetes care. Federation I. International Diabetes Federation: IDF Diabetes Atlas. Brussels, Belgium 33: S62-S69. 